\title{
Forum Shopping in Times of Crisis: A Directors' Duties Perspective
}

\author{
by
}

Irit Mevorach*

Some systems have more efficient legal frameworks for insolvency than other regimes, thus directors of troubled companies may seek opportunities abroad. Yet, the legitimacy of forum shopping in close proximity to insolvency is debatable in the context of cross-border insolvency regimes. This paper examines the forum shopping phenomenon from a new perspective, that of directors' duties in times of financial trouble, specifically in light of emerging international standards in this area. This method allows unearthing the degree to which forum shopping is legitimate. This paper also shows how the directors' duties regime is better fit to deal with illegitimate forum shopping compared with cross-border insolvency frameworks.

Table of Contents

ECFR 2013, 523-553

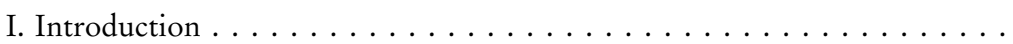

II. Forum Shopping - Casting a Shadow on the Efficacy of Cross-Border In-

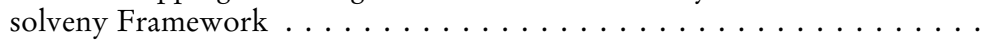

III. Directors' Obligations in the Period Approaching Insolvency: Emerging International Benchmarks . . . . . . . . . . . . . 533

IV. Forum Shopping within a Directors' Duties Framework . . . . . . . . . . 533

1. Relocation as a way to minimise the effect of insolvency . . . . . . . . . . 538

2. The ambit of legitimate forum shopping . . . . . . . . . . 539

3. The benefits and limitations of the COMI test . . . . . . . . . . . . 540

4. Dealing with wrongful relocations via directors' duties regimes . . . . 542

5. Accessible and effective remedies . . . . . . . . . . . . . . 544

6. Conflicts among creditors . . . . . . . . . . . . . . . . 546

7. False claims regarding the COMI . . . . . . . . . . . . . . . 547

8. Neglect of creditors in the host country . . . . . . . . . . . . . 548

V. Problems of Harmnoziation and Compliance . . . . . . . . . . . . . . 548

VI. Concluding Remarks . . . . . . . . . . . . . . . . . . . . . . 552

* Associate Professor, University of Nottingham (LLB, LLM, Tel Aviv University; PhD, UCL). I would like to thank Ian Fletcher and Adrian Walters for insightful comments on earlier versions of the article. The usual disclaimers apply. 


\section{Introduction}

Forum shopping by corporations in close proximity to insolvency is a subject of heated debate. ${ }^{1}$ In particular, cross-border insolvency regimes, which are aimed at harmonising the private international law aspects of insolvency, have struggled to deal with this problem effectively. The controversy has become especially acute in recent years in view of a perceived increase in corporate relocations prior to corporations' insolvency. Examples include relocations to the UK of Hellas Telecommunications, European Directories, and Gallery Capital before the companies instituted insolvency proceedings. ${ }^{2}$ Indeed, the UK in particular has established itself as a popular venue for the restructuring of failing enterprises, apparently because of the attractive features of the company voluntary arrangement procedures and pre-pack administrations. ${ }^{3} \mathrm{How}-$ ever, debtor forum shopping in close proximity to insolvency is not confined to movements into the UK. ${ }^{4}$

The paper considers the forum shopping phenomenon from the perspective of directors' duties in the period approaching insolvency. ${ }^{5}$ Indeed, the regulation of management duties in terms of their trading decisions during the time leading up to insolvency and the legitimacy of debtor forum shopping tend to be considered as two separate issues and have been the subject of distinct initiatives and debates. ${ }^{6}$ However, both issues relate to managerial pre-crisis

1 The article focuses on eve of insolvency corporate forum shopping which involves a relocation of the company. This should be contrasted with forum shopping by manipulating or misrepresenting facts related to the company's location (which does not in fact involve a relocation; see further on this scenario n 118-122 and accompanying texts), and forum shopping after the commencement of insolvency proceedings. Corporate forum shopping in the ordinary course of business and forum shopping in civil litigation are also beyond the scope of this article.

2 Re European Directories (DH6) BV [2010] EWHC 3472 (Ch); Re Hellas Telecommunications (Luxembourg) II SCA [2009] EWHC 3199 (Ch) [2010] BCC 295; Gallery Capital S.A v In the Matter of Gallery Media Group Ltd (2010) WL 4777509.

3 See e.g. the Da Movo, IMO car wash and Wind Hellas enterprises that migrated to the UK in order to take advantage of the pre-pack strategy. See also H Eidenmüller, 'Abuse of law in the context of European insolvency law' (2009) 6 European Company and Financial Law Review 1, 5.

4 See e.g. the case of PIN Group SA (Amtsgericht Köln, 19 February) (73 IE 1-08).

5 'Director' for the purpose of this paper means anyone who plays a role in the company's management either formally (de jure directors) or informally (de facto directors), or through controlling the managers or giving them instructions (often referred to as 'shadow directors', see e.g. English Insolvency Act, s 214(7) and 251) (hereinafter: directors or managers).

6 See on the one hand, initiatives in Europe regarding directors' duties in the context of the EU harmonization programme (Report of the High Level Group of Company Law Experts of 4 November 2002, Ch. III; Study on Directors' Duties and Liability (April 
decisions and therefore raise similar risks. In particular, the possibility that directors will act in a self-serving manner in the time leading up to insolvency or make decisions harmful to creditors is relevant to both trading and relocation decisions (to the extent that directors anticipate opportunities abroad). There is, therefore, sense in controlling both of these aspects of decisionmaking in a consistent manner, and in attempting to reconcile the approach to forum shopping under cross-border insolvency frameworks with what is generally expected from directors when the company is in financial crisis. This is especially the case since international standards regarding directors' obligations in the period approaching insolvency are emerging, as a result of the work undertaken by UNCITRAL. 7 That is, what is expected of directors at the time leading up to insolvency is becoming an international matter. In fact, the decision of UNITRAL to standardise the rules regarding directors' duties was driven by the reality of globalized insolvencies and the need to control managers' behaviour on a worldwide basis and achieve consistent solutions. ${ }^{8}$

The fact that an international regime is emerging in this area also suggests that there is scope for controlling problems of mismanagement on a worldwide basis, to the extent that national regimes would comply with the new benchmarks. Indeed, the paper will also argue that the new directors' duties regime is a more adequate tool for dealing with problems related to the forum shopping practice, than cross-border insolvency frameworks would be. Thus, the paper aims both to contribute to the debate regarding the legitimate ambit of forum shopping and to point to an alternative measure that could address detrimental forum shopping. The conclusions could also shed light on the efficacy of current reform initiatives concerning the main cross-border insolvency frameworks. ${ }^{9}$

The paper begins (in Part II) by delineating the scope of the forum shopping debate in the context of cross-border insolvency frameworks and the implications of the forum shopping controversy on the prominence of the cross-

2013), http://ec.europa.eu/internal_market/company/board/) and similar initiatives of UNCITRAL in the context of harmonization of insolvency laws (United Nations Commission on International Trade Law [UNCITRAL] Legislative Guide on Insolvency Law 2004 (hereafter: the UNCITRAL Legislative Guide), para 34; new recommendations on directors' duties that will be added to the Legislative Guide, discussed in Part III of the paper). Cf. the reform of cross-border insolvency frameworks and the discussion of forum shopping in this context (discussed in Part II of the paper).

7 United Nations Commission on International Trade Law. See further part III below.

8 See Part III below.

9 The European Regulation on Insolvency Proceedings is undergoing revision (the redrafting process is likely to end during 2014). Working Group V of UNCITRAL has recently revised the Guide to Enactment of the UNCITRAL Model Law on Cross-Border Insolvency. These frameworks are discussed in Part II of the paper. 
border insolvency regimes. Subsequently (in Part III), the paper examines the emerging benchmarks in the area of directors' duties during the period approaching insolvency and the underlying rationale for these benchmarks. Part IV examines what these new benchmarks reveal with regard to the forum shopping debate and the extent to which the directors' duties regime could play an effective role in addressing problems of forum shopping. Part V discusses possible obstacles to the uniform adoption of the international benchmarks. Part VI concludes.

\section{Forum Shopping - Casting a Shadow on the Efficacy of Cross-Border Insolveny Frameworks}

The field of cross-border insolvency has developed quite rapidly in recent years. From a state of almost total chaos resulting from the application of conflicting domestic private international laws, it is gradually becoming an area regulated by uniform frameworks. ${ }^{10}$ The EU Regulation governs crossborder insolvencies within Europe. ${ }^{11}$ The UNCITRAL Model Law ${ }^{12}$ is the main global framework for cross-border insolvency. It applies to any country that opts to adopt it, ${ }^{13}$ while creditors and office-holders from any other country may also invoke the Model Law in the adopting States.

These frameworks support the centralization of insolvency proceedings in the company's home country, which is its centre of main interests (COMI), i.e. its real economic centre, presumed to be located at its registered office. ${ }^{14}$ Thus, the EU Regulation provides that only the country in which the COMI is located can open the main proceedings against the debtor. ${ }^{15}$ The Model Law too requires that proceedings will be recognized as main proceedings only if they were opened in the jurisdiction in which the COMI is located, and only one such main proceeding may be recognized. ${ }^{16}$ The COMI forum would then ideally be in a position to administer the process collectively, under the same set of laws, overseeing the complete affairs of the company and including all

10 See generally IF Fletcher, Insolvency in Private International Law (Oxford 2005).

11 European Regulation on Insolvency Proceedings (Council Regulation 1346/2000) (hereafter: EU Regulation), which applies whenever the centre of main interests of the debtor is located in a Member State, except Denmark which has not participated in the adoption of the Regulation.

12 United Nations Commission on International Trade Law (UNCITRAL), UNCITRAL Model Law on Cross-Border Insolvency with Guide to Enactment, U.N. Sales No. E.99.V.3 (hereafter: the UNCITRAL Model Law or Model Law).

13 Thus far 20 countries have adopted the Model Law.

14 The EU Regulation, art. 3(1).

15 Ibid.

16 Model Law, arts. 2(b) and 16(3) and 17(2)(a). 
creditors in the process. Indeed, subject to a public policy exception, the EU Regulation requires that other Member States would automatically recognize the opening of main proceedings, without reviewing the decision regarding the location of the COMI. ${ }^{17}$ Under the Model Law, the foreign office-holder must seek recognition of the foreign proceedings as the main proceedings. ${ }^{18} \mathrm{How}-$ ever, (and again subject to a similar public policy exception ${ }^{19}$ ) recognition should be granted swiftly if the court finds that the COMI is present in the foreign jurisdiction. ${ }^{20}$ Under both regimes, though, it is possible that additional proceedings will be opened in other countries. The EU Regulation allows the opening of secondary proceedings if the debtor company has an established presence in another Member State. ${ }^{21}$ Under the Model Law, the court may recognize other foreign proceedings as non-main proceedings (in addition to recognizing the main proceedings in the COMI jurisdiction). ${ }^{22} \mathrm{It}$ may also open local proceedings after the recognition of the main proceedings, if there are assets in the jurisdiction. ${ }^{23}$ However, both regimes require cooperation among the multiple proceedings concerning the same debtor. ${ }^{24}$ The extent of the global perspective of the main proceedings under the Model Law will also depend on the type of relief that the recognizing court would grant with regard to the foreign proceedings, as only some relief is automatic, ${ }^{25}$ while the rest is discretionary. ${ }^{26}$ Furthermore, the Model Law does not provide choice-of-law rules and therefore deference to the laws of the forum would depend on receiving relief to this extent from the recognizing court. Under the EU Regulation, on the other hand, the opening of the main proceeding has automatic EU-wide effect and the office-holder appointed in the main proceedings may exercise all the powers conferred on him by the law of the State where proceedings were opened. ${ }^{27}$ Indeed, the law of the forum (of the main proceedings) would apply to most insolvency matters arising in the course of the proceedings. ${ }^{28}$ Thus, although there are notable differences between the

17 The EU Regulation, art. 16 and 26.

18 Model Law, art. 15. Indeed, multiple main proceedings may be opened anywhere in the world, but the recognizing court can recognize only one set of main proceedings under the Model Law's scheme.

19 Model Law, art. 6.

20 Model Law, arts. 15-17.

21 EU Regulation, art.3(2).

22 Model Law, arts. 2(c) and 17(2)(b)).

23 Model Law, art. 28.

24 EU Regulation, art. 31 (cooperation between liquidators in main and secondary proceedings). Model Law, art. 25-27 (cooperation between courts and insolvency representatives in the enacting States and the foreign jurisdiction).

25 Importantly, the stay of proceedings (Model Law, art. 20).

26 Model Law, art. 21.

27 EU Regulation, art. 18.

28 EU Regulation, art. 4. This is subject to a list of exceptions (arts. 5-15). 
models and notwithstanding mechanisms enshrined in the models for opening multiple proceedings or ways to deny recognition, both regimes are premised on an international (universalist) approach, which seeks to promote a global universal perspective over international insolvencies, primarily via the jurisdiction of the debtor's economic centre..$^{29}$

One notable struggle with regard to the formulation and operation of these regimes, though, has been how to tackle forum shopping, specifically the relocation of the COMI at the time approaching insolvency. There has clearly been a desire to address the issue within the cross-border insolvency frameworks, yet it has been difficult to develop practical solutions, which are also justified by a coherent rationale. The EU Regulation has explicitly denounced the practice of moving assets or proceedings with the motive of improving the company's legal position. ${ }^{30}$ Yet, it did not provide explicit means to address forum shopping within the body of the Regulation. The European Commission proposes to retain the same approach of "forum shopping avoidance" (in the forthcoming revised Regulation), but to refer more specifically to forum shopping that is detrimental to the general body of creditors. ${ }^{31}$ The proposals also seek to minimise the problem of forum shopping by requiring courts to examine their jurisdiction ex officio and by granting all foreign creditors a right to challenge the opening decision. ${ }^{32}$ The Model Law does not mention the issue of forum shopping within its provisions. However, the Guide to Enactment of the Model Law was recently revised, ${ }^{33}$ and it is now suggested that courts should carefully scrutinize the debtor's circumstances where the COMI was moved shortly before the com-

29 See generally JL Westbrook, 'A Global Solution to Multinational Default' (2000) 98 Mich L Rev 2276.

30 The EU Regulation, Preamble, Recital 4.

31 European Commission, Proposal for a Regulation of the European Parliament and of the Council amending Council Regulation (EC) No. 1346/2000 on insolvency proceedings, 12.12. 2012 COM(2012) 744 final (hereafter: European Commission Proposal), proposed amendment to recital 4.

32 Ibid, proposed new article $3 \mathrm{~b}$.

33 See UNCITRAL Working Group V (Insolvency Law), Forty-third session, New York, 15-19 April, 2013 'Interpretation and application of selected concepts of the UNCITRAL Model Law on Cross-Border Insolvency relating to centre of main interests (COMI)‘, A/CN.9/WG.V/WP.112; hereafter: UNCITRAL WP.112, and A/CN.9/ 766, Report of Working Group V (Insolvency Law) on the work of its forty-third session (New-York, 15-19 April 2013); hereafter: Report, forty-third session). The final text of the revised Guide to Enactment would be available in due course on the UNCITRAL website (http://www.uncitral.org). The author had the privilege of participating in the deliberations as adviser to the United Kingdom delegation. All views expressed here, though, are solely those of the author. 
mencement of the proceedings. ${ }^{34}$ It is noted in working papers in this respect that there may be instances where the move was designed to thwart the legitimate expectations of creditors and third parties or was undertaken as the result of insider exploitation or biased motivation. ${ }^{35}$

Courts applying the cross-border insolvency frameworks have also struggled with the problem of forum shopping. Examining the case law reveals a somewhat undecided approach, which is understandable in the absence of a clear notion of the ambit of acceptable forum shopping and in view of the difficulties of evaluating reasons and motivations for relocation. Thus, in some cases it is apparent that courts regard corporate relocations prior to the institution of insolvency proceedings with suspicion and resentment, ${ }^{36}$ while in other cases they tend to focus on whether the COMI is actually located in the (new) jurisdiction without any further investigation. ${ }^{37}$ The Court of Justice of the European Union (ECJ) provided some clarification in the Interedil case, ${ }^{38}$ where it accepted that the registered office of the company might move from one jurisdiction to another and noted that the most recent location is what counts. It also did not express any concern with regard to forum shopping and did not suggest that it might be a harmful or an illegitimate practice. However, in this case, the relocation took place long before the commencement of the proceedings. It was not a case of forum shopping in close proximity to the insolvency proceedings. ${ }^{39}$

The problem of forum shopping has also been a major source of continuous attack on the efficacy of cross-border insolvency frameworks. Generally, the idea of centralizing proceedings in the home country of the corporate debtor has been subject to academic criticism, largely because of the alleged instability, unpredictability, and risk of abusive relocation of any identified corporate centre. "Territorialists", who have advocated the split of insolvency proceed-

34 The Working Group has also clarified that the location of the COMI should be determined with reference to the time when the foreign proceeding was commenced (WP.112, para 128C). Cf. Fairfield Sentry Ltd 11-4376 (2nd Cir. 2013).

35 See WP.112, para $123 \mathrm{~K}$.

36 See Shierson v Vlieland-Boddy [2005] 1 WLR 3985 and Official Receiver v Eichler [2007] BPIR 1636, HCJ; Die Sparkasse Bremen AG v Armutcu (2012) Ch D (concerning individuals); Ci4net.com Inc [2005] BCC 277 (Ch D); TXU Europe German Finance $B V, \operatorname{Re},[2005]$ BCC 90 (Ch D). In the context of the Model Law see Fairfield Sentry Ltd 11-4376 (2nd Cir. 2013) where the court noted that there may be room in relevant cases to consider COMI manipulations in bad faith between the date of commencement of the proceedings and the date of the application for recognition.

37 See e.g. Re European Directories (DH6) BV [2010] EWHC 3472 (Ch); Re Hellas Telecommunications (Luxembourg) II SCA [2009] EWHC 3199 (Ch) [2010] BCC 295.

38 Interedil Srl (Case C-396/09) [2011] ECR.

39 Ibid paras 10-11. 
ings among the countries where the company's assets are located, have argued that it is too difficult to locate the home country of a debtor company, especially in cases of large enterprises operating as corporate groups. ${ }^{40}$ Even if some test for identifying the home country were provided (be it the place of incorporation, assets, or the location of the head office of a company), multinational companies would always be able to manipulate the forum. To an extent, the locations of assets and operations are more difficult to change (so the argument goes), but even these can be moved..$^{41}$ Multinational groups have even greater opportunities for shifting their centres, as they can achieve the change through acquisitions and divestitures. ${ }^{42}$ Specifically, it has been claimed that using the COMI test as the solution for the home country conundrum cannot control the problem of forum shopping. The COMI is argued to be a 'movable feast'. ${ }^{43}$ The test is too fuzzy, vague, and prone to manipulation since the determination of the location of the real economic centre is very fact sensitive. ${ }^{44}$

It has been argued further that relocation of the prospective insolvency forum may be detrimental to creditors. Thus, directors may act self-servingly, seeking to move to legal regimes that are favourable to them while escaping liabilities, or may move exclusively in order to harm a particular group of creditors. ${ }^{45}$ Although it has been acknowledged that relocation of the COMI may actually benefit creditors in certain circumstances ${ }^{46}$ it has been difficult to point to the dividing line between good and bad forum shop-

40 See LM LoPucki 'Cooperation in International Bankruptcy: A Post-Universalist Approach' (1999) 84 Cornell L Rev 696, 716-25; LM LoPucki, 'Universalism Unravels' [2005] 79 Am Bankr L J 143, 152-58. Indeed, currently, the cross-border insolvency frameworks do not address the case of the corporate group and do not suggest a jurisdictional test in this context (see generally I Mevorach, Insolvency within Multinational Enterprise Groups (Oxford University Press, 2009).

41 LM LoPukci, Courting Failure: How Competition for Big Cases Is Corrupting the Bankruptcy Courts (Ann Arbor 2005) 229.

42 Ibid.

43 See G McCormack, 'Jurisdictional Competition and Forum Shopping in Insolvency Proceedings' (2009) CLJ 169, 196.

44 See e.g. H Eidenmüller, 'Free Choice in International Company Insolvency Law in Europe' (2005) 6 EBOR 423, 428 and 430-31; DA Skeel, 'European Implication of Bankruptcy Venue Shopping in the US’ (2007) 54 Buff L Rev 439, 463; WG Ringe, 'Forum shopping under the EU Insolvency Regulation' (2008) EBOR 580, 612; P Torremans, 'Coming to Terms with the COMI Concept in the European Insolvency Regulation' in P.J. Omar (ed), International Insolvency Law Themes and Perspectives (Aldershot, 2008) 173, 181; McCormack, Jurisdictional Competition (n 43) 196.

45 See e.g. Eidenmüller, Abuse (n 3$) 11$.

46 See G Moss, IF Fletcher and S Isaacs, The EC Regulation on Insolvency Proceedings (Oxford 2009) 262; Eidenmüller, Abuse (n 3$) 11$. 
ping. ${ }^{47}$ Specifically, it has been noted that whether or not there has been abuse may be difficult to judge, ${ }^{48}$ and that relocation may be good for some creditors but not for others. ${ }^{49}$ Some have suggested that forum shopping is not abusive if all creditors have consented to the move..$^{50}$ Others have suggested that the test should be whether there was an actual increase in the net assets of the company following the migration (in which case forum shopping would not be deemed abusive), ${ }^{51}$ or whether or not the relocation was fraudulent. ${ }^{52}$

In this light, it may well be the case that even with the forthcoming clarification in the cross-border insolvency regimes that illegitimate forum shopping would be confined to relocation that is detrimental to the general body of creditors, there would be uncertainty regarding the ambit of legitimate forum shopping. Specifically, questions could arise regarding the actual meaning of detrimental forum shopping and the basis for establishing detriment in this context. Would the company be required to prove that the relocation took place with the consent of all or most creditors? Alternatively, would it need to show that the relocation resulted in an increase of the net assets? To what extent should courts be engaged in investigating the circumstances of insider exploitation or biased motivation pertaining to relocation when considering applications for recognition of foreign proceedings, especially in view of the requirement that recognition applications should be decided upon at the earliest possible time?

Indeterminacy of the scope of forum shopping and problems in applying rules regarding detrimental forum shopping might at some point lead to replacing the COMI test (which is the focal point of the cross-border insolvency regimes) with a statutory seat test (i.e., one which is based on the place of incorporation or the registered office).${ }^{53}$ Indeed, some commentators argue

47 See J Armour, 'Abuse of European Insolvency Law? A Discussion' in R de la Feria \& S Vogenauer (eds), Prohibition of Abuse of Law: A New General Principle of EU Law? (Oxford 2011) 164.

48 See Eidenmüller, Abuse (n 3) 16.

49 A Walters and A Smith, “Bankruptcy tourism' under the EC Regulation on insolvency proceedings: a view from England and Wales’ IIR 2010, 19(3) 181, available at SSRN: http://ssrn.com/abstract=1630890, 39.

50 P Paschalidis, Freedom of Establishment and Private International Law for Corporations (Oxford 2012), 221.

51 See Eidenmüller, Abuse (n 3$) 16$.

52 See Moss et al, The EC Regulation (n 46) 262; Paschalidis, Freedom (n 50) 217-21. See also Advocate General (Colomer) Opinions in Staubitz-Schrieber C-1/04 paras 7-77 and in Frick Teppichboden C-339/07 who has pointed out that Community Law combats opportunistic and fraudulent choices of jurisdiction and not "forum shopping" per se.

53 This can be contrasted with the 'real seat' approach underlying the COMI concept, which refers to the actual economic centre of the debtor company. 
that a rule that requires companies to file for bankruptcy in their place of incorporation will make the venue rule more certain and less manipulable. ${ }^{54}$ Furthermore, the argument holds that such a test will ensure that creditors are protected in case of reincorporation prior to the commencement of insolvency proceedings, at least in Europe, as the 10th EC Directive will require conforming to the creditor protection rules established by the laws of the affected Member States. ${ }^{55}$ Admittedly, even with the forthcoming reforms of the cross-border insolvency frameworks, which now propose to focus on specific factors for identifying the COMI (primarily the location of the company's headquarters / central management), ${ }^{56}$ COMI will remain, to an extent, fact sensitive and thus arguably prone to manipulation. COMI determination would still require a comprehensive assessment of all relevant factors. ${ }^{57} \mathrm{~A}$ formalistic test, which would be based on the statutory seat, could indeed be more straightforward. However, such a jurisdictional test (in the context of insolvency) entails numerous disadvantages, not least related to the fact that it might direct insolvency cases to jurisdictions to which the company has no genuine connection. ${ }^{58}$

Generally, a sustained debate regarding the problem of forum shopping could cast doubt on the merit of universalist cross-border insolvency frameworks. It will be suggested below that the new emerging directors' duties regime (discussed in the next section) could shed light on the extent to which forum shopping should be allowed. It also has the potential to address problems of detrimental forum shopping more effectively than cross-border insolvency frameworks would.

\section{Directors' Obligations in the Period Approaching Insolvency: Emerging International Benchmarks}

In a different context, UNCITRAL ${ }^{59}$ undertook to deliberate on the topic of directors' obligations in the period leading up to insolvency, ${ }^{60}$ as it considered

54 See e.g. Skeel, European Implication (n 44) 463; L Perkins, 'Note, A Defense of Pure Universalism in Cross-Border Corporate Insolvencies' (2000) 32 NYU J INT'L L \& POL 787; Torremans, Coming to terms (n 44) 181.

55 Eidenmüller, Abuse (n 3) 13.

56 In the current versions of the Regulation and the Model Law, COMI is not defined (it is only presumed to be located at the place of the registered office).

57 See European Commission Proposal, proposed amendments to recital 13 article 3; UNCITRAL WP.112, paras 123D-123I.

58 See I Mevorach, 'Jurisidction in Insolvency: A Study of European Courts' Decisions' (2010) 6(2) JPIL 327, 332-35. See further $n 88$.

59 Via Working Group V (Insolvency Law).

60 See UNCITRAL Working Group V (Insolvency Law) Forty-third session, New York, 
it important to seek a degree of standardisation in this area and enhance the objectives of the Model Law and the UNCITRAL Legislative Guide. ${ }^{61}$ This work has proceeded against the backdrop of a myriad of approaches and a degree of uncertainty as to the actual duties imposed on directors in the time leading up to insolvency in different legal systems. Indeed, insolvency is often a gradual and incremental process; thus, it is hard to define in precise terms the point in time after which insolvency is foreseeable and creditors are at risk and may be harmed by the actions of the managers. Generally, the dilemma is whether to defer to the business judgement of directors during that time or to impose specific obligations to protect creditors during the period approaching insolvency. Some regimes are very protective of creditors and impose a strict duty on directors to initiate insolvency proceedings within a short period after the occurrence of an insolvency event. ${ }^{62}$ In other regimes, directors owe their duties to the company at all times and this does not change as insolvency approaches. ${ }^{63}$ Other systems adopt "wrongful trading" provisions (in various forms) ${ }^{64}$ which essentially impose a duty on directors to give due regard to the interests of creditors when they realize that insolvent liquidation is inevitable. ${ }^{65}$ Some laws provide additional remedies aimed at compensating creditors for fraudulent behaviour or at deterring mismanagement. ${ }^{66}$

Drawing from this range of regulatory options, the Working Group of UNCITRAL has decided to focus on tackling mismanagement that falls short of

15-19 April 2013, 'Directors' obligations in the period approaching insolvency', A/ CN.9/WG.V/WP.113 (hereafter: UNCITRAL WP.113) and Report, forty-third session. The deliberations were concluded recently and the new recommendations will be added as Part IV of the UNCITRAL Legislative Guide. The final text would be in due course available on the UNCITRAL website (http://www.uncitral.org). The author had the privilege of participating in the deliberations as adviser to the United Kingdom delegation. All views expressed here, though, are solely those of the author.

61 A/CN.9/715, Report of Working Group V (Insolvency Law) on the work of its thirtyninth session (Vienna, 6-10 December 2010) para 56 (hereafter: Report of thirty-ninth session).

62 This is a common approach in civil law jurisdictions. See e.g. GmbH-Gesetz, $\$ 64(1)$, Aktiengesetz, $\mathbb{\$} 92(2))$.

63 See e.g. Canadian Business Corporations Act 1985, s 241(2)(c); Peoples Department Stores Inc. $v$ Wise [2004] SCC 68 [43], though creditors may have redress via oppression remedies. See generally INSOL International, 'Directors in the Twilight Zone III' (2009) 706.

64 See in the UK, s 214 of the Insolvency Act 1986.

65 Other regimes which adopt a wrongful trading regime include Australia, New Zealand, Singapore and South Africa. See generally JL Westbrook, CD Booth, C Paulus and H Rajak, A Global View of Business Insolvency Systems (The World Bank, 2010) 54.

66 See e.g. the English Company Directors Disqualification Act 1986; the English Insolvency Act 1986, s 213 (imposing liability for fraudulent trading) and the English Companies Act 2006, s 993 (the criminal offence of fraudulent trading). 
fraud in the period approaching insolvency while acknowledging that legal regimes may impose additional measures to deter misconduct. ${ }^{67}$ In this respect, the Working Group specifically favoured flexibility and deference to directors' judgement over the more restrictive approaches. ${ }^{68}$ Thus, the new standards on directors' obligations in the period approaching insolvency, which will be added to the UNCITRAL Legislative Guide, assert that they aim to encourage directors to consider rescue possibilities in times of financial crisis, avoiding risk aversion. It is specifically stated that provisions addressing the obligation of directors and remedies for breach of duties should be implemented in a way that does not adversely affect successful reorganization, does not discourage participation in the management of companies, and does not prevent the exercise of reasonable business judgement or the taking of reasonable commercial risk. ${ }^{69}$

At the same time, the recommendations acknowledge that creditors may be at risk in the period leading up to insolvency and therefore that directors (defined in broad terms ${ }^{70}$ ) must consider creditors' interests when making decisions during this time. Thus, the recommendations state that when insolvency is imminent or unavoidable, the legitimate interests of creditors, as well as those of other stakeholders, should be protected and that appropriate remedies for breach of duties to consider these interests should be provided. ${ }^{71}$ Specifically, it is recommended that directors take reasonable steps to avoid insolvency, or minimise its extent when it is unavoidable. ${ }^{72} \mathrm{~A}$ range of steps may be reasonable in the relevant circumstances. ${ }^{73}$ These might include the initiation of

67 See WP.113, recommendation 12.

68 See Report of thirty-ninth session, para 55.

69 UNCITRAL Working Group V (Insolvency Law) Forty-third session, New York, 1519 April 2013, Directors' obligations in the period approaching insolvency', A/CN.9/ WG.V/WP.113, recommendations 1 and 2, purpose of legislative provisions (hereafter: UNCITRAL WP.113).

70 The obligation is imposed on those making decisions concerning the management of a company. Liability may extend to those exercising factual control, which could include parent companies or creditors (UNCITRALWP.113, recommendations 1 and 2 purpose of legislative provisions, and recommendation 4). The Working Group also considers to specifically address issues related to directors of enterprise group members (see UNCITRAL Working Group V (Insolvency Law) Forty-third session, New York, 15-19 April 2013, 'Enterprise groups- Directors' obligations in the period approaching insolvency', A/CN.9/WG.V/WP.115). These aspects are outside the scope of this paper.

71 UNCITRAL WP.113, recommendations 1 and 2, purpose of legislative provisions.

72 Ibid., recommendation 1.

73 Steps may include: (a) Evaluating the current financial situation of the company and ensuring proper accounts are being maintained and that they are up-to-date; being independently informed as to the current and ongoing financial situation of the company; holding regular board meetings to monitor the situation; seeking professional advice, including insolvency or legal advice; holding discussions with auditors; calling 
formal insolvency proceedings. However, the proposed standards do not suggest that directors should be obliged to file for insolvency within a specific period of time. Furthermore, the time at which the obligations above arise is not defined in precise terms; rather it generally corresponds to a state of factual insolvency, actual or imminent, before insolvency proceedings have begun. The steps that should be taken by directors are not prescriptive either, and they may vary depending on the circumstances. The approach is thus akin to wrongful trading-type provisions, seeking to hold directors accountable for misconduct and negligent management and protecting creditors from the deterioration of the company's estate close to insolvency, but not penalizing (but rather, even encouraging) attempts to turn failing businesses around.

The rationale underlying this policy choice is certainly strong and is consistent with the set of internationally recognized goals of insolvency. Thus, it had been agreed almost a decade ago (while deliberating on the UNCITRAL Legislative Guide) that insolvency laws should strive to achieve a range of goals in a balanced manner. ${ }^{74}$ Creditors' wealth should be maximised and their rights respected, though a series of considerations should be taken into account. Importantly, the law should balance between liquidation and reorganization, and the choice between these procedures may reflect social considerations beyond wealth maximisation, including the encouragement of entrepreneurship and preservation of employment. ${ }^{75}$ This corresponds with the "traditionalist" approach to insolvency law, proclaiming that insolvency law has a broad role to play and a wide range of interests to accommodate. ${ }^{76} \mathrm{It}$ should give centrality to distributional concerns and look to the survival of companies as well as to their orderly liquidation, ${ }^{77}$ offer opportunities for

a shareholder meeting; modifying management practices to take account of the interests of creditors and other stakeholders; protecting the assets of the company so as to maximize value and avoid loss of key assets; considering the structure and functions of the business to examine viability and reduce expenditure; not committing the company to enter into the types of transaction that might be subject to avoidance unless there is an appropriate business justification; continuing to trade in circumstances where it is appropriate to do so to maximize going concern value; holding negotiations with creditors or commencing other informal procedures, such as voluntary restructuring negotiations; (b) Commencing or requesting the commencement of formal reorganization or liquidation proceedings. See ibid., recommendation 2.

74 UNCITRAL Legislative Guide, Part one, B, para 3.

75 Ibid Part one, B, para 6.

76 The opposing "proceduralist" approach sees insolvency law as a mere collectivised debt collection device and focuses on a single objective- maximising the collective return to creditors (see e.g. TH Jackson, The Logic and Limits of Bankruptcy Law (Harvard University Press, 1986); DG Baird, 'The Uneasy Case for Corporate Reorganisations' (1986) 15 Journal of Legal Studies 127).

77 See e.g. E Warren, 'Bankruptcy Policymaking in an Imperfect world' (1993) 92 Mich L 
continuation, reorganization, and rehabilitation, and provide time for adjustments. ${ }^{78}$ Since UNCITRAL's agreement on the insolvency goals, the emphasis on enabling rescues has gained further support, and to date the process of rescue and rehabilitation of businesses is recognized by all international treaties dealing with insolvency and is provided for in a substantial number of legal systems. ${ }^{79}$ Indeed, full rescues of companies may be a practical option in but only a minority of cases, and a rehabilitation is often not feasible, but the idea is to provide a legal environment that would allow some sort of rescue (even if only of the business) in cases where the business is viable. In this respect, early action by those who are aware of the company's financial situation is crucial.

The proposed directors' duties regime follows this balanced approach. On the one hand, it aims to promote efficiency and maximise wealth by reducing financial agency costs associated with management's perverse incentives to take excessive risks at the expense of creditors in the period approaching insolvency. ${ }^{80}$ At the same time, the proposed benchmarks direct policy makers to avoid a regime, which is too strict, that is, one that would prohibit insolvent trading or oblige directors to take all possible steps when the company is facing difficulties. As a result, directors may not be too risk averse when operating within such a framework and could be encouraged to consider rescue possibilities or other solutions that would be beneficial to the body of creditors and other stakeholders, as soon as they realize that the company is in financial difficulties.

\section{Forum Shopping within a Directors' Duties Framework}

Allowing directors to relocate the company when facing financial trouble could generally fit with the obligation enshrined in the new international benchmarks discussed above. Under the proposed regime, directors would

Rev 336; DR Korobkin, 'Contractarianism and the Normative Foundations of Bankruptcy Law’ (1993) 71 Texas L Rev 541.

78 See V Finch, Corporate Insolvency Law (Cambridge University Press, 2009$) 46$.

79 Westbrook et al, A Global View (n 65) 124. See also the recently published communication from the EU Commission to the European Parliament proposing a new European approach to business failure and insolvency. Specifically, it is suggested that Europe would create an efficient system to restore and reorganize businesses so that they can survive the financial crises, operate more efficiently and when necessary, make a fresh start (Communication from the Commission to the European Parliament, the Council and the European Economic and social Committee, A new European approach to business failure and insolvency, $\operatorname{COM}(2012) 742$ final, 12.12. 2012).

80 See e.g. A Keay, 'The Director's Duty to Take into Account the Interests of Company Creditors: Where is it triggered' (2001) 25 Melb Univ L Rev 318; RJ Mokal, Corporate Insolvency Law: Theory and Application (Oxford 2005) 274-77. 
be expected to take steps to search for a solution that would benefit the company's stakeholders as a whole and in particular to consider the feasibility of rescuing the business or the company. Indeed, such solutions may be available in foreign legal systems. This part of the paper will consider the ambit of legitimate forum shopping when considered from the perspective of directors' duties. It will also show how the directors' duties regime might control detrimental forum shopping. Finally, it will distinguish between the problem of detrimental forum shopping and other scenarios of abuse and conflict concerned with the opening of insolvency proceedings in a cross-border context.

\section{Relocation as a way to minimise the effect of insolvency}

In the absence of a fully harmonized insolvency regime and unified restructuring procedures, differences between legal regimes are still significant. Even within Europe, insolvency laws vary considerably and Member States' systems offer a range of advantages and disadvantages to financially troubled companies. ${ }^{81}$ In practice, companies have occasionally taken advantage of this range of insolvency options and relocated their COMI to a foreign jurisdiction before the initiation of insolvency proceedings in order to facilitate a rescue or a restructuring. In the PIN Group case, for example, the company directors sought to initiate proceedings in Germany, following the move of the company's COMI from Luxembourg, in order to save the group as a whole. ${ }^{82}$ In Gallery Capital, the COMIs of the BVI and Luxembourgian companies were relocated to the UK in order to pursue a restructuring via the UK scheme of arrangement procedure. ${ }^{83} \mathrm{~A}$ corporate migration of this sort, that is, one that is aimed at seeking better insolvency outcomes for the business in distress, for the benefit of the creditors and other stakeholders, is largely consistent with the aim and underlying policy of the directors' duties regime proposed as an international benchmark. It expands the options available to directors seeking the best solution for the company and the creditors as a whole.

The costs of relocation must be considered, though. Indeed, migration may be expensive and may delay the effective administration of the debtor's affairs. ${ }^{84}$

81 Indeed, the UK restructuring procedures have been particularly attractive to foreign companies due to the flexibility which English insolvency law grants companies in this respect, as noted in the recent Impact Assessment (of the EC Insolvency Regulation) published by the European Commission (European Commission, Impact Assessment Accompanying the document Revision of Regulation (EC) No.1346/2000 on insolvency proceedings, 12.12.2002, SWD (2012) 416 final, p 20).

82 PIN Group SA (Amtsgericht Köln, 19 February) (73 IE 1-08).

83 Gallery Capital S.A v In the Matter of Gallery Media Group Ltd (2010) WL 4777509.

84 See Walters and Smith, Bankruptcy tourism (n 49) 33. 
Specially, if the COMI test is adopted (and it will be argued below that it should be) the relocation will involve giving notices to creditors and establishing an actual economic link in the new jurisdiction, which could entail greater costs compared with a regime, which would allow more tenuous connections with the new jurisdiction. Whether or not relocation can assist insolvency avoidance or minimise the effect of insolvency depends, therefore, on wider considerations of relocation implications beyond a mere comparison of available procedures in the local and the foreign fora. Yet, where all of the above implications have been properly considered, a decision to relocate could comply with the directors' obligations in the period leading up to insolvency.

\section{The ambit of legitimate forum shopping}

While the directors' duties regime generally supports relocation, its legitimacy would depend on whether or not the relocation was predicated on a desire to improve the position of the general body of creditors. Therefore, self-serving relocations for the purpose of escaping liabilities, prolonging the entry into insolvency proceedings, retaining the managing position and so forth, as well as relocations aimed at benefiting a section of the stakeholders must be regarded detrimental (i.e. wrongful). ${ }^{85}$ Such relocations cannot meet the standard duty of taking steps near insolvency to avoid insolvency or minimise its affect for the benefit of the stakeholders as a whole.

This does not imply, though, that relocations, which turned out to be unsuccessful or relocations affected without the consent of all creditors are necessarily detrimental. The directors' duties regime requires consideration of the interests of the stakeholders as a whole, rather than negotiating with every stakeholder. Indeed, seeking the consent of all stakeholders before moving to a different jurisdiction could be time consuming and even unrealistic in an insolvency environment where there may be numerous stakeholders with competing interests. It could also result in "holdout" strategies by creditors who may seek to curtail a beneficial move to gain an advantage on the expense of the general body of creditors. Requiring that the relocation be successful, in that it maximised the net assets, in order to escape liabilities, would also be too stringent. Specifically, such ex post examination of the effect of the move would be contrary to the flexible directors' duties regime, which balances between creditor protection and promotion of rescues, encouraging directors to consider responsibly what could be the best option for their business. Thus, liability should not be premised on measuring the degree of success of the

85 As a minimum standard. Relocation may also be fraudulent. 
migration but rather the reasonableness of the directors' decision to take such a step.

\section{The benefits and limitations of the COMI test}

Legitimising some type of forum shopping under cross-border insolvency frameworks would be, therefore, consistent with the general benchmarks regarding directors' obligations in the period leading up to insolvency. Thus, the fact that the COMI may be moved or that relocations as such are not always prevented is not, from the viewpoint of the directors' duties regime, a problem. In fact, the ability to move is consistent with the obligation regime, and thus there is less scope for criticising cross-border insolvency frameworks on these grounds. Preventing detrimental (i.e., wrongful) forum shopping is also compatible with the directors' duties regime. Yet, there is only so much that the cross-border insolvency regime itself, namely the private international aspects of insolvency, can do to address situations of debtor detrimental forum shopping.

Indeed, by imposing a jurisdictional test such as COMI, which focuses on the actual economic centre of the company, cross-border insolvency regimes assist in preventing detrimental forum shopping. This sort of test also meets the concern of cross-border insolvency regimes that ascertaining jurisdiction would be consistent with creditors' expectations regarding the location of the insolvency process. It is inherent to the COMI test that creditors must remain on board in the course of relocation decisions in the period leading up to insolvency. The test requires that the insolvency forum be ascertainable by third parties. ${ }^{86}$ Migration of the actual COMI would involve, therefore, consultation and negotiations with the creditors from the new location during the period before the institution of the proceedings, ${ }^{87}$ making it harder for companies to relocate self-servingly. The recent proposed refinements of the COMI analysis which suggest that the test will be primarily based on a key connecting factor, the actual centre of management of the company, would further limit the choice of forum to a specific location and one to which the company has a real economic connection. ${ }^{88}$

86 See European Insolvency Regulation, Recital 13. The ECJ in Eurofood IFSC Ltd (Case C-341/04) [2006] and in Interedil Srl (Case C-396/09) [2011] emphasized the importance of the ascertainability of COMI.

87 This is compatible with the guidance provided in Irish Bank Resolution Corporation v Quinn [2012] NICh 1 at [28] regarding the requirement that COMI should be ascertainable by third parties.

88 See European Commission Proposal, proposed amended art. 3(1); UNCITRAL wp. 112, para $123 \mathrm{~F}$ and Report, forty-third session, para 38. The COMI test entails 
Any jurisdictional test can be manipulated, though. Thus, directors may not reveal the actual motivation for a move of the COMI and breach their obligations to the creditors as a whole. This is true whether a jurisdictional test is based on the company's COMI or on its statutory seat. The registered office, too, could be manipulated before commencing insolvency ${ }^{89}$ Indeed, economic analysis predicts that directors will be more prone to take excessive risks at the expense of creditors at times of financial difficulty. Thus, when considering relocation, directors may tend to dismiss the potential costs of a move, as they have less to lose and more to gain by seeking new opportunities at a time of distress. They may even move especially and deliberately to evade liabilities and to achieve personal gains, if they foresee that insolvency proceedings are approaching. Especially the weaker unsecured creditors might not be in a position to protect themselves from such risks in the period approaching insolvency. ${ }^{90}$ Sophisticated, powerful creditors may be in a relatively better position and require that the company not only inform them but also consult with them prior to COMI movements. Indeed, directors may collude with some of the creditors in the course of relocation, or negotiate with a fraction of the stakeholders, if it seems that the prospects abroad may benefit that fraction over other creditors. ${ }^{91}$

Yet, the efficacy of cross-border insolvency frameworks would be curtailed if courts applying the frameworks would need to go beyond the COMI determination to verify whether the relocation was detrimental. Thus, claims re-

various other important advantages. As it reflects a real seat of the company, it prevents the process from being handled in "haven" jurisdictions in which the company may have incorporated for various reasons but to which the company has no genuine connection (see JL Westbrook, 'Locating the Eye of the Financial Storm' 32 BROOK J INT'L L 1019, 1030). Where the cross-border insolvency case involves members of a corporate group, the COMI test often allows centralization of the proceedings at the meeting point (central administration) of all the group entities that, although they had their registered offices in different countries, were all centrally controlled and therefore had their COMIs in the same forum. This can prevent multiple proceedings and allows for the achievement of group-wide rescues or going concern sales of the business as a whole (see I Mevorach, 'The Home Country of a Multinational Enterprise Group Facing Insolvency' 57 ICLQ 427; Mevorach, Jurisdiction (n 58) 334. See also European Commission Proposal, proposed new Recital 20 b).

89 See Hughes v. Hannover Ruckversicherungs-Aktiengesellschaft [1997] 1 BCLC 497 (CA) where a company devised a 'redomestication' scheme whereby it re-registered in Bermuda and then asked to be wound up there, leaving behind in the US the profitable parts of the business (hived down to a new company) and abandoning the creditors with asbestos related claims. See further Fletcher, Insolvency (n 10) 222, 238-9.

90 c.f. Ringe, Forum shopping (n 44) 602, who argues that it is the creditor's responsibility to take protection against such risks (e.g. by including 'anti-migration' covenants and warranties in the lending agreements).

91 See also Walters and Smith, Bankruptcy tourism (n 49) 39. 
garding the motivations and consequences of relocation may involve complex issues of law and evidence that might need to be tested at full trial. Decisions on commencement and recognition of insolvency proceedings based on crossborder insolvency models, on the other hand, must be swift. ${ }^{92}$ In addition, even if a court opening insolvency proceeding could address forum shopping allegations promptly, a refusal to open insolvency proceedings in the new jurisdiction, even though the COMI was relocated to that jurisdiction from the original forum, could entail significant additional costs. It would require the COMI to be moved back to the original forum. Otherwise, if the COMI were to remain in the new forum but the proceedings were opened in the original one, the scheme of the cross-border insolvency framework (requiring matching the COMI with the place where proceedings would be administered) would be distorted. There may also be costs involved in handling the case in a forum that no longer represents the economic centre of the company, in terms of gathering information and evidence.

Considering the legitimacy of forum shopping at the recognition stage is even more problematic. It would mean second-guessing the decision of the court that opened the original proceedings. This would entail adverse consequences in terms of certainty and finality of judgements, international cooperation, and the need to give prompt effect to the opening of insolvency proceedings. Indeed, allegations regarding wrongful relocation would normally fall below the high threshold of the "public policy" exception under which recognation could be denied. ${ }^{33}$ Even where forum shopping involved defrauding creditors (which might amount to a public policy matter), it would be more effective to deal with any such allegations at a later stage of the process, especially if the claims require further investigation, rather than to deny recognition.

\section{Dealing with wrongful relocations via directors' duties regimes}

The new international standards on directors' obligations in the vicinity of insolvency has the potential to provide an alternative regime for dealing with detrimental relocations of companies. The standards are not confined to

92 The European Insolvency Regulation proclaims that: '.. cross-border insolvency proceedings should operate efficiently and effectively and this Regulation needs to be adopted in order to achieve this objective...' (recital 2); Art. 17(3) of the Model Law requires that an application for recognition of a foreign proceeding shall be decided upon at the earliest possible time.

93 Recognition may be denied only where it would be "manifestly" contrary to public policy to recognise the foreign proceedings, i.e. when the opening proceedings in the foreign court prevented fair trial (see Eurofood IFSC Ltd (Case C-341/04) [2006] at [6068]). 
wrongful trading as such, but rather they require more generally that directors take reasonable steps to avoid insolvency or minimise its extent (at times of financial distress) while having due regard for the interests of creditors and other stakeholders. ${ }^{94}$ Decisions regarding the location of filing for insolvency could be regarded as falling within the scope of such obligations. In this respect, going abroad may be a step in the right direction, as suggested above, so long as the directors considered the downsides of relocation and their decision was predicated on a desire to benefit the creditors as a whole. Considering the complexities involved in moving the company to a different jurisdiction it would be desirable, though, to require that directors attempting to take such a step accompany it with certain additional steps that would support the decision and ensure its viability and overall benefit. These may include seeking professional advice regarding the implications of the relocation, including about any obstacles in the local jurisdiction in terms of restructuring opportunities and the likelihood of a decrease in value of the business if the options available locally are pursued. For the same reason, it would also be desirable to go somewhat beyond the usual steps expected of directors making decisions in the period approaching insolvency and require that they be able to positively demonstrate and justify that their decisions and actions were predicated on a desire to act in the best interests of creditors as a whole. In other words, in cases of relocations in close proximity to insolvency, the burden would be on the directors to show that they had taken into account the benefits and the effects on the general body of creditors and had reached the decision to relocate the company with such considerations in mind. Specifically, they should be able to demonstrate that at the time of deciding to relocate it appeared that going abroad would result in a better outcome for the creditors as a whole compared with staying in the original jurisdiction.

It would be wrong, though, to view beneficial relocations that had the potential to result in a better outcome to creditors as required steps to take before initiating insolvency proceedings. First, there may be countless different opportunities abroad, of which directors may not be aware. Seeking information about all possible solutions beyond what is available locally cannot be regarded a reasonable step, which is what the obligations' regime requires..$^{95}$ Second, even where directors become aware of certain opportunities abroad,

94 UNCITRAL WP.113, recommendation 2. It should be noted that even where legislation refers specifically to wrongful trading, trading in this respect probably includes nontrading activities (see regarding the English regime R Goode, Principles of Corporate Insolvency Law (Sweet \& Maxwell 2011) 667).

95 c.f. the English wrongful trading provision which provides a defence for directors who took every step (with a view to minimising the potential loss to the company's creditors) when they first acquired deemed knowledge that insolvent liquidation was inevitable. Yet, other elements of the provision refer to what is reasonably expected of persons 
they may consider it undesirable to move the company to a different country, not because it does not provide an efficient system for corporate rescue, but due to other legitimate business considerations. Indeed, business decisions concerned with entering into foreign markets, or else remaining local, are often led by economic factors. ${ }^{96}$ Cultural differences may also be relevant. Especially if reorganization is sought, the location of the actual centre of the recovered company could be critical, and the company may not want to go through the process of moving back to the original forum once again.

\section{Accessible and effective remedies}

Directors' duties regimes, if compatible with the international benchmarks, could therefore address detrimental forum shopping. Allegations against directors could be raised, for example, in the COMI forum, but not necessarily at the time when the proceedings are opened. The COMI forum may apply its directors' duties laws if the choice of law rule under the relevant cross-border insolvency framework refers to the law of the forum with regard to insolvency related matters. Indeed, as the matter of directors' pre-insolvency duties is closely linked to insolvency, there is merit in the concentration of the litigation against directors in the COMI forum and in the application of its laws. This approach would neatly correspond with the EU Regulation scheme, which as noted above, provides that, subject to exceptions, the law applicable to insolvency proceedings and their effects shall be that of the insolvency forum (where proceedings are opened). ${ }^{97}$ The EU Commission also proposes to add a provision to the EU Regulation, which will clarify that the insolvency forum shall have jurisdiction over actions related to insolvency. It is specifically mentioned in this respect that this could be the case if the liquidator wishes to combine an action for director's liability based on insolvency law with an action based on company law or general tort law. ${ }^{98}$ Thus, even if the relevant directors' duties regime is provided for in a law other than insolvency law, and this is the basis of the action against the director, the action may be pursued in the insolvency forum. As noted above, the Model Law does not provide for jurisdiction and choice-of-law rules. It is, therefore, possible under the Model Law's scheme to either invoke the COMI's forum laws (and seek to recognize and enforce the judgement in the receiving court), or to invoke the laws of the enacting State. This gives parties a degree of flexibility when

carrying on the same functions, which suggest that 'every step' actually means every reasonable step (see Goode, Principles of Corporate Insolvency Law (n 110) 673).

96 See PT Muchlinski, Multinational Enterprises and the Law (Oxford 2007) 40.

97 European Insolvency Regulation, art. 4.

98 European Commission Proposal, proposed art. $3 \mathrm{a}$ and proposed recital $13 \mathrm{~b}$. 
attempting to pursue culpable managers, but in any event, the proceedings will be based on invoking directors' duties regimes at any stage of the proceedings without delaying the recognition process.

It is crucial, though, that a directors' duties regime would be accessible and that it could be called upon effectively. It might be somewhat unrealistic to expect that office-holders would instigate proceedings against directors in the course of rescue proceedings, particularly where the same office-holders acted in an advisory capacity in connection to the relocation. Indeed, the actions against the directors may be brought later in a successor proceeding, e.g. a liquidation arising after administration. Yet, to increase the effectiveness of the regime, it is important that remedies against directors will be available in the course of other types of proceedings, i.e. that they can be invoked by administrators or trustees, and not only by liquidators. ${ }^{99}$ Creditors should also be allowed to bring such actions. The court itself should be required to consider the effects of relocation and in the relevant circumstances prompt office-holders to instigate an investigation or to take into account the implications of the move in the context of a proposed reorganization plan. Courts may also impose conditions when opening insolvency proceedings or when recognizing foreign proceedings, with regard to further investigations against directors or, when it is clear that relocation involved misconduct, regarding possible contributions from directors or subordination of their claims. In cases of conflict of interests, it should be possible to appoint a different office-holder who may be in a better position to take on board such investigations.

Another problem is how to fund the litigation. Office-holders may be reluctant to utilize funds of the insolvency estate to cover the costs of initiating and handling the proceedings, especially given that success cannot be guaranteed. The UNCITRAL recommendations regarding directiors' pre-insolveny duties acknowledge this problem and suggest that the insolvency law should specify that the costs of proceedings against a director be paid as administrative expenses and that the law may provide alternative approaches to address the pursuit and funding of such proceedings. ${ }^{100}$ The commentary to the recommendations mentions such possible different approaches, including assigning, for value, the right to commence the proceedings to a third party. It is also

99 This is compatible with UNCITRAL's recommendations that enforcement of the remedies will not be limited to specific types of proceedings (UNCITRAL WP.113, recommendations 1 and 2, purpose of legislative provisions). See also current proposal of the UK government to make fraudulent and wrongful trading remedies available in administration (http://www.bis.gov.uk/assets/insolvency/docs/insolvency\%20profession/consultations/redtapechallenge/rtc-consultation.pdf). 
mentioned that in some instances, claims against directors might be settled. ${ }^{101}$ This could reduce costs and minimize efforts of finding further funding, especially in circumstances where the likelihood of success is doubtful.

It should also be borne in mind that in some cases, the scale of the company's losses may be many times more than the directors' means- individually and collectively- to compensate those who have suffered losses. Including remedies such as subordination of directors' claims to those of external creditors (or the elimination of such claims) in addition to contribution orders could provide some additional compensation in situations where directors have claims against the company as creditors, releasing more of the insolvency estate for external creditors. Additionally, where the company is a member of a corporate group often other entities, usually a parent company, may be the director (broadly defined) and is likely to have a deeper pocket. ${ }^{102}$

Generally, it must be acknowledged that wrongful trading proceedings are to some extent a speculative venture, especially since the regime is flexible and does not prescribe a specific time when directors should consider the interests of the creditors. Nonetheless, it is still preferable to address issues related to debtor misconduct in the course of the insolvency process rather than at the stage of opening or recognizing foreign proceedings, for the reasons explained above. It is also important to clarify to directors what is required of them when they consider relocation, with the expectation that this will deter mismanagement.

\section{Conflicts among creditors}

Wrongful relocation should be distinguished from scenarios in which a decision to move, although predicated on a desire to benefit the stakeholders as a whole, was harmful to some of the creditors. Indeed, creditors may have conflicting interests with regard to a given relocation, especially owing to differences in the priority rules of the respective insolvency systems. Thus, a particular group of creditors might be worse off because of the relocation even if the move is considered beneficial overall. The solution in such cases may be compromises, determined on a case-by-case basis. Thus, when creditors are able to show that they could have received more in proceedings in the original jurisdiction from which the COMI was moved, this may be taken into account in the course of devising the scheme in the new forum or by way of applying the foreign (rather than the forum's) law. It would be a more effective solution

101 UNCITRAL WP.113, para 51.

102 See I Mevorach, The role of enterprise principles in shaping management duties at times of crisis (forthcoming, EBOR). 
than returning a case to the original forum or commencing multiple proceedings. Similar solutions have been devised in practice to avoid the opening of additional territorial (i.e., secondary) proceedings in cross-border insolvencies under the EU Regulation, whereby the court of the main proceedings applies the law of the secondary forum without actually opening secondary proceedings, thus preventing the associated cost of conducting multiple proceedings. ${ }^{103}$

\section{False claims regarding the COMI}

Cases involving wrongful relocations should also be distinguished from cases of abuse of process whereby debtors deliberately misrepresent the COMI or falsely claim that COMI is in a particular jurisdiction. Examples include, in Europe, the case of Hans Brochier, ${ }^{104}$ in which the debtor distorted the facts to claim that the company's head office was in the UK, while it was actually in Germany. ${ }^{105}$ On the global level, in Cenargo, ${ }^{106}$ the company, foreseeing its collapse, attempted to pick the US as its bankruptcy jurisdiction. ${ }^{107}$ For this purpose, the English parent company and various subsidiaries presented a Chapter 11 petition in the US, even though the only connection the group had to the US was bank accounts opened shortly prior to the opening of proceedings and the fact that certain creditors were based in the US. ${ }^{108}$

These types of cases fall within the ambit of the cross-border insolvency frameworks under which the court should ascertain the connecting factors between the company and the jurisdiction i.e. the location of the COMI. Indeed, in these cases the investigation of which jurisdiction is the proper one should result in refusal to open proceedings (or refusal to recognize the proceedings as the main proceedings under the recognition-based regimes),

103 See e.g. Re Collins E Aikman Corp Group [2005] EWHC 1754 (Ch).

104 Hans Brochier Holdings Ltd v Exner Chancery Division [2006] EWHC 2594 (Ch), [2007] BCC 127.

105 Indeed, the English court (finding that COMI was actually in Germany) refused to open main proceedings in the UK.

106 Re Norse Irish Ferries E Cenargo Navigation Limited (unreported, 20 February 2003); In re Cenargo International Plc, 294 BR 571 (Bankr SDNY 2003)). The case took place prior to the adoption of the Model Law in UK and US legislation.

107 This enabled the directors to remain in control through the 'debtor in possession' notion.

108 See LM LoPucki, Courting Failure: How Competition for Big Cases Is Corrupting the Bankruptcy Courts (Ann Arbor 2005) 189, 191-3 and 204-205. See also Yucos Oil Co, $\operatorname{Re}$ (Unreported, February 24, 2005) (SD Tex (US)) and G. Moss, 'Dismissal of Yucos Chapter 11 Proceedings' (2005) 18(5) Insolv Int 77. 
since the COMI is not present in the new forum. The question in these cases is where the COMI is rather than whether its relocation was wrongful.

\section{Neglect of creditors in the host country}

Another possible scenario, which might be confused with situations of wrongful relocation, would involve a COMI move whereby the new forum neglects the foreign creditors. In this scenario, the move might have been predicated on a desire to benefit some creditors as a whole, but in fact, the new forum fails to accommodate some foreign creditors. These scenarios too should be controlled by the cross-border insolvency regime. Indeed, the cross-border insolvency models require that foreign creditors not be discriminated against. ${ }^{109}$ All creditors should have the right to be heard and right to participate in the proceedings. ${ }^{110}$ If the new forum nonetheless discriminates against foreign creditors and denies them of their right to due process, the public policy exception in the cross-border insolvency models should apply, as a basis for non-recognition and subsequently, where required, the opening of local proceedings. The same conclusion might be reached, in the old forum, in cases where the COMI has moved but no proceedings were opened by the company in the new forum and creditors are not in a position to open such proceedings themselves, since the new forum denies them of due process or is otherwise manifestly unfair.

\section{Problems of Harmnoziation and Compliance}

For the directors' duties regime to work effectively it must also be available worldwide. Otherwise, the court that will deal with the company's insolvency (e.g., the COMI forum, subject to the relevant choice of law rule) may not be equipped to address breaches of the relevant duties. Directors, in turn, may not be deterred from acting wrongly, since their predicted tendency to be more adventurous at this stage would not be fully controlled. They will be able to seek more lenient regimes unless forum shopping is denied, but in that case, the benefit of relocation would be curtailed as well.

This highlights the importance of the new standards developed by UNCITRAL, though obviously their effectiveness depends on compliance at the

109 European Insolvency Regulation, arts. 39 and 40; Model Law, arts. 13 and 14.

110 See also the European Commission proposal to improve the procedural framework for determining jurisdiction, which is aimed at ensuring that creditors can effectively exercise their rights in the court seized of the request to open insolvency proceedings (text to $\mathrm{n} 32$ ). 
national level, namely on actual harmonization and standardisation in this area. Sceptics of harmonization would raise the concern that legal diversity yields solutions that are more efficient for companies since managers can then cherry-pick the most suitable regime for their company. ${ }^{111}$ This argument is less forceful, though, with regard to rules addressing management behaviour close to the time of insolvency when creditors are the main concern and directors' conduct is less likely to be controlled by market forces. ${ }^{112}$ Additionally, compliance with benchmarks regarding directors' duties does not entail a wholesale harmonization of the insolvency laws. Importantly, legal regimes may still develop their own rescue procedures. In fact, because the emerging benchmarks regarding directors' duties put much emphasis on deference to directors' business judgement and on encouraging rescues, they can be understood as allowing relocations that are aimed at seeking viable reorganization solutions. Therefore, the benchmarks could promote rather than impede corporate mobility and constructive competition. Harmonization of pre-crisis managerial behaviour rules would make the migratory process a race to the top, though, rather than to the bottom.

Harmonization entails another risk, though, since it could prevent innovation and result in the stagnation of legal regimes, which may become inflexible and unresponsive to changing market conditions and firm demands. ${ }^{113}$ Yet, this problem is more apparent with regard to rigid top-down harmonization in the form of, for example, directly applicable regulations or binding directive, ${ }^{114}$ while a legislative guide merely contains recommendations which local policy makers may or may not follow. Indeed, this high degree of flexibility could be a critical limitation of the benchmarks as means of standardisation. It can be predicted that the standards, which will appear in the UNCITRAL Legislative Guide as a set of non-binding recommendations, will not make any actual impact on national legal systems, which will remain diverse and will fail to meet the proposed benchmark. Indeed, it has been argued that harmonization

111 See RK Winter, 'State Law, Shareholder Protection, and the Theory of the Corporation' (1977) 6 Journal of Legal Studies 251, 291-2; DR Fischel, 'The "Race to the Bottom” Revisited: Reflections on Recent Developments in Delaware's Corporate Law' (1982) 76 Nw U L Rev 913, 922; FH Easterbrook, 'The Race for the Bottom in Corporate Governance' (2009) 95 Va L Rev 685, 688.

112 LA Bebchuk, 'The Debate on Contractual Freedom in Corporate Law, Forward to Symposium, Contractual Freedom in Corporate Law' (1989) 89 Colum L Rev 1395, 1405-06; FH Easterbrook and DR Fischel, 'The Corporate Contract' 89 Colum L Rev 1416, 1436-42.

113 See e.g. L Enriques and M Gatti, 'The Uneasy Case for Top-Down Corporate Law Harmonization in the European Union' (2006) 27 U Pa J Int'l Econ L 939, 973 and 976.

114 Under EC law, directives require implementation and thus allow some flexibility in the transposition into national laws, however Member States are bound by the Directives' principles (Treaty on the Functioning of the European Union, art.288). 
of substantive insolvency laws is generally unattainable given the lack of a supranational authority that can command uniformity. ${ }^{115}$ It was argued further that this suggests that harmonization depends on reaching a consensus on the relevant rules, but even where such agreement is achievable, it may not be a real consensus, but rather the result of dominant groups' pressures on the expense of other stakeholders. ${ }^{116}$

However, the work undertaken by UNCITRAL (the body that adopted the standards) builds on wide representation and is based on thorough deliberations which culminate in consensual decisions. ${ }^{117}$ Arguments regarding the attainability of harmonization also underestimate current pressures on insolvency systems to converge. ${ }^{118}$ Specifically, the emerging benchmarks already reflect some similarity in the approaches of domestic regimes to directors' preinsolvency duties. The recommendations were drawn from national experiences. Indeed, UNCITRAL has found that notwithstanding the differences in how directors' obligations are formulated, the underlying rationale may be similar and certain common aspects of the required standards can be identified. ${ }^{119}$ The recommendations, therefore, may not totally "reinvent the wheel" for many legal systems, but assist in refining existing laws when these may undergo revision or renovation. Indeed, the general task of the UNCITRAL Legislative Guide is twofold - to identify common ground and to suggest how to revise laws to meet new challenges, i.e., to harmonize and to modernize. ${ }^{120}$ Specifically, for legal systems like that of the UK, which adopt wrongful trading provisions that are generally compatible with the benchmarks, taking note of the international deliberations could assist in clarifying, for example, the steps that are regarded as reasonable when attempting to avoid insolvency, as a matter of international consensus. ${ }^{121}$ Importantly, with regard to the problem of forum shopping, the acceptance of the directors' duties regime on the international level could provide legitimacy for accepting companies into the jurisdiction if they attempt to make use of developed reorganization or re-

115 EJ Janger, 'Universal Proceduralism' (2007) 32 Brook J Int'l L 819, 831.

116 Ibid 834.

117 See S Block-Lieb and T Halliday, 'Incrementalisms in Global Lawmaking' (2007) 32 Brook J Int'l L 851, 899, noting that the legitimacy of the work undertaken by UNCITRAL is built on three foundations: representativeness, procedural fairness and effectiveness.

118 Specifically because it is an area which requires market symmetry (see Westbrook, A Global Solution (n 29) 2288-92).

119 UNCITRAL Working Group V (Insolvency Law), Forty-first session, New York, 30 April- 4 May, 2012, 'Directors' obligations in the period approaching insolvency', A/ CN.9/WG.V/WP.104, para 28.

120 See S Block-Lieb and T Halliday, 'Harmonization and Modernization in UNCITRAL Legislative Guide on Insolvency Law' (2007) 42 Tex Int'l L J 475, 476-7 and 488-98.

121 The UK wrongful trading provision does not delineate any such steps. 
structuring regimes. At the same time, it could be accepted that if directors did not have due regard for creditors' interests in the process and they are not able to justify their move in view of their general obligations, they may be liable for their actions.

The benchmarks can be even more significant for less developed regimes or for regimes that are so strict as to impede rescues. ${ }^{122}$ It is also becoming apparent that the UNCITRAL Legislative Guide is making some actual impact on national laws. The Working Group of UNCITRAL noted in one of its recent meetings that '[S]everal international organizations reported on activities relating to the promotion of UNCITRAL texts and noted in particular the extensive use of the Legislative Guide as a basis for law reform and the dissemination of information on the work of UNCITRAL'. ${ }^{123}$ It is not inconceivable, therefore, that national policy makers will also consider the new recommendations on directors' duties favourably. It is also hoped that the European regulator will have regard for the new standards, especially because within the EU, being an integrated market, harmonization endeavours in corporate insolvency law are more likely. Indeed, the EU Parliament has put forward a proposal for the harmonization of certain matters pertaining to insolvency law. ${ }^{124}$ The EU Commission has decided to consider the proposal further. ${ }^{125}$ Alarmingly, though, some aspects of EU Parliament proposal seem incompatible with the obligations regime formulated on the international level, as they suggest adopting a uniform rule, which would require the opening of insolvency proceedings within a short period of time after the cessation of payment. ${ }^{126}$ In its communication, though, the Commission notes the differences between legal regimes in terms of rules for mandatory filing of insolvency and seems to accept that imposing tight timeframes in this respect could adversely affect the company's ability to solve its financial difficulties. ${ }^{127}$

122 See A/CN.9/715, Report of UNCITRAL Working Group V (Insolvency Law) on the work of its Thirty-ninth session (Vienna, 6-10 December 2010), para 62.

123 See A/CN.9/742, Report of UNCITRAL Working Group V (Insolvency Law) on the work of its Forty-first session (New York. 30 April- 4 May 2012), para 103.

124 European Parliament resolution with recommendations to the Commission on insolvency proceedings in the context of EU company law, 2011/2006(INI) - 15/11/2011 (hereafter: European Parliament resolution).

125 Communication from the Commission to the European Parliament, the Council and the European Economic and Social Committee, A new European approach to business failure and insolvency, 12.12.2012 COM (2012) 742 final, ch 5 (hereafter: Communication from the Commission).

126 European Parliament Resolution, Part 1, para 1.1.

127 Communication from the Commission, ch 3, para 3.3. It also commissioned a study on "Directors' duties and liabilities in the EU" (prepared for the European Commission, DG Market by LSE Enterprise, London, December 2012: http://ec.europa.eu/internal_market/company/board/index_en.htm). 


\section{Concluding Remarks}

Forthcoming amendments of the main cross-border insolvency frameworks are likely to resolve the indeterminacy that surrounded the jurisdictional test enshrined in these regimes, by refining the meaning of COMI. ${ }^{128}$ They are also likely to limit manipulation of the COMI location, as the test would become even more focused on a specific connecting factor and on the actual economic centre of the company. The clarifications concerning COMI movement are also welcomed since they may restrict attacks on relocations in the vicinity of insolvency to situations of detrimental forum shopping only. Commendably, thus far suggestions to impose "look-back" periods that would restrict movements to specific period of time before the initiation of insolvency proceedings were not taken on board. ${ }^{129}$ This restrained approach regarding the forum shopping phenomenon is compatible with the balanced and flexible regime adopted by UNCITRAL regarding directors' obligations in times of financial crisis. However, it is unlikely that the cross-border insolvency frameworks as such, even after their renovation, would fully resolve the forum shopping debate and provide the appropriate means for tackling debtor misconduct prior to insolvency. It might still be unclear what would amount to detrimental forum shopping under the frameworks and how detriment might be proved in the course of opening or recognizing foreign insolvency proceedings.

The ambit of legitimate forum shopping would become clearer, though, if the forum shopping dilemma is linked directly to the regulation of directors' duties in the vicinity of insolvency. In this regard, the regime agreed upon on the international level now requires that when insolvency is predicted, directors should take active steps to minimise the extent of insolvency and avoid it where possible. Forum relocation could be seen as the taking of such steps, where it was predicated on the desire to benefit the creditors as a whole. Accordingly, directors or other corporate controllers involved in a decision to relocate should be able to demonstrate the motivation for the move and to

128 See $\mathrm{n} 96$ and accompanying text.

129 See e.g. proposals published by INSOL Europe which suggest that if COMI was moved less than a year before the commencement of proceedings, then the previous COMI will have international jurisdiction, so long as liabilities to creditors remain unpaid and unless those creditors consent in writing to the transfer (Revision of the European Insolvency Regulation, Proposals by INSOL Europe, proposed amendment to article 3(1) of the European Insolvency Regulation). Cf.: Global Principle 13.5 of the American Law Institute and the International Insolvency Institute, "Transnational Insolvency Global Principles for Cooperation in International Insolvency Cases”, Report (2012) (IF Fletcher and B Wessels, Joint Reporters) which proposes a similar concept but with no time limits and a degree of flexibility in determining whether creditors were prejudiced as a result of the relocation. See also Walters and Smith, Bankruptcy tourism (n 49) 47-48. 
show that they considered its effect on the general body of creditors. Detriment or benefit should not be based, though, on whether or not a move was in fact successful or on whether it was affected with the approval of all the creditors. The directors' duties regime, if adopted in national laws, also has the potential to address more effectively situations of wrongful forum shopping, compared with cross-border insolvency models, which necessitate swift decisions regarding the opening and recognition of insolvency proceedings. Cross-border insolvency regimes would operate more smoothly if they focus on determining the location of the company's centre while further enquiries regarding the circumstances surrounding relocation would be addressed in the context of directors' duties litigation. 